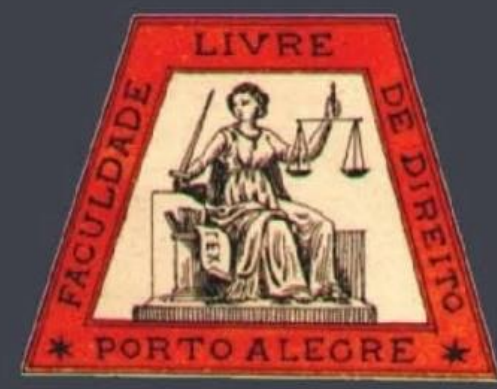

\title{
Desobediência civil e objeção de consciência: distinções
}

Civil disobedience and conscientious objection: distinctions

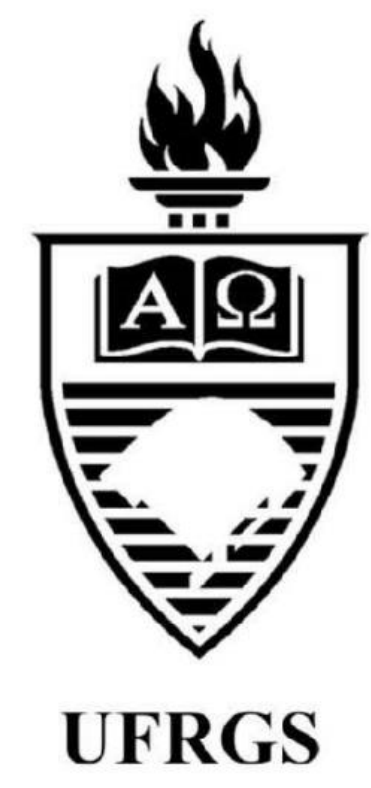

André Luiz Carvalho Greff

Universidade Estadual de Mato Grosso do Sul

Vânia Mara Basilio Garabini

Universidade Estadual de Mato Grosso do Sul 


\title{
Desobediência civil e objeção de consciência: distinções
}

\author{
Civil disobedience and conscientious objection: distinctions
}

André Luiz Carvalho Greff*

Vânia Mara Basilio Garabini**

\section{REFERÊNCIA}

GREFF, André Luiz Carvalho; GARABINI, Vânia Mara Basilio. Desobediência civil e objeção de consciência: distinções. Revista da Faculdade de Direito da UFRGS, Porto Alegre, n. 36, vol. esp., p. 169-181, out. 2017.

\section{RESUMO}

O presente artigo pretende empreender um estudo de caso, contemplando a situação do jovem Añaki Arredondo Garcia, que se negou ao cumprimento de serviços alternativos, aplicados em substituição à prestação do serviço militar, na Espanha, por ser de convicção pacifista, tentando classificar essa sua decisão como desobediência civil ou objeção de consciência, contemplando o pensando de alguns teóricos como Thoreau, Dworkin, Paula López Zamora, Martha E. S. Obregón e Raúl R. Canizales, Jesus Lima Torrado, entre outros.

PALAVRAS-CHAVE

Desobediência civil. Objeção de consciência. Negativa de cumprimento de serviço militar.

\section{ABSTRACT}

The present paper intends to implement a case study, contemplating the situation of the young Anaki Arredondo Garcia, who refused to comply with the alternative services, applied in lieu of the provision of military service in Spain for his pacifist conviction, trying to sort this decision of him as civil disobedience or conscientious objection, contemplating the thought of some theorists like Thoreau, Dworkin, Paula López Zamora, Martha E. S. Obregón and Raúl R. Canizales, Jesus Lima Torrado, among others.

\section{KEYWORDS}

Civil disobedience. Conscientious objection. Refusal to comply with military service.

\section{SUMÁRIO}

Introdução. 1. A desobediência civil para Henry David Thoreau. 2. A desobediência civil para Ronald Dworkin. 3. Desobediência civil e objeção de consciência para Paula L. Zamora. 4. A desobediência civil para Martha E. S. Obrégon e Raúl Ruiz Canizales, comparados com a opinião de Jesus Lima Torrado. Conclusão. Referências.

\section{INTRODUÇÃO}

No curso de pós-graduação stricto-senso, em nível de mestrado, ofertado pela Universidade Federal do Mato Grosso do Sul - UFMS - Fadir, de Campo Grande - MS, na disciplina de Fundamentos Antropológicos dos Direitos Humanos, o Doutor Jesus Lima Torrado, Professor de Filosofia da Universidade
Complutense de Madri, apresentou aos discentes, para estudo de caso, isso no período de 11 a 15 de abril de 2016, a situação de Añaki Arredondo Garcia, que foi processado criminalmente em Madri, na Espanha, no ano de 1991, por ter descumprido a prestação de serviço alternativo, atividade substitutiva à prestação de serviço militar obrigatório, sendo que terminou o acusado por ser absolvido pelo juiz da causa ${ }^{1}$.

\footnotetext{
* Mestrando em Direitos Humanos da Fadir - UFMS.

*** Professora universitária na graduação e na pós-graduação na Universidade Estadual de Mato Grosso do Sul.

${ }^{1}$ ESPANHA. Administración de Justicia. Juzgado de lo Penal Madrid - n. 4. Sentencia num. 75/92 - 2I6190129, 03. Fev. 1992. Juez Jose Luis Calvo Cabello.
} 
Um resumo do caso pode ser encontrado no Jornal El País, de 7 de março de $1992^{2}$, sob o título "Un juez absuelve a un insumiso al entender que la libertad de consciencia está por encima del Estado".

No Brasil, o serviço miliar é obrigatório ao menos no tocante à apresentação no ano em que um homem completa 18 anos, todavia, a Constituição Federal, no seu artigo 143, parágrafo primeiro possibilitou também a prestação militar alternativa, mediante simples alegação de objeção de consciência.

Sobre a objeção de consciência, esclarece José Carlos Buzanello3:

$\left.1^{\circ}\right)$ objeção de consciência ao serviço militar dispõe basicamente sobre o recrutamento e o exercício militar, possibilitando aos indivíduos o direito a evitar o serviço militar bélico aos que tenham apreensões de natureza religiosa acerca de lutar ou matar. A objeção de consciência ao serviço militar é omissiva, individual, personalíssima, pacífica, parcial.

$\mathrm{Na}$ Constituição da Espanha, em seu artigo 30, conforme Nicolas Garcia Rivas ${ }^{4}$, disciplina que:

1. Los españoles tienen el derecho y el deber de defender a España. 2. La ley fijará las obligaciones militares de los españoles y regulará, con las debidas garantías, la objeción de consciência, así como lás demás causas de exención del SM obligatorio, pudiendo imponer, en su caso, una prestación social sustitutoria.

Añaki Arredondo Garcia fora dispensado do serviço militar obrigatório, na Espanha, com a

\footnotetext{
${ }^{2}$ HERNANDÉZ, António José. Un juez absuelve a un insumiso al entender que la libertad de consciência está por encima del Estado. Madri, 7 mar. 1992. El País. Disponível em

http://elpais.com/diario/1992/03/07/espana/699922819_85 0215.html> . Acesso em 20 mai.2016.

${ }^{3}$ BUZANELLO, José Carlos, Objeção de consciência: uma questão constitucional. Revista de Informação Legislativa. Brasília a. 38 n. 152 out/dez 2001 (p. 173-182). Disponível em:

https://www2.senado.leg.br/bdsf/bitstream/handle/id/730/r 152-13.pdf?sequence=4, acesso em 01 Dez. 2016.
}

condição de que comparecesse à prestação do serviço substitutivo obrigatório. E uma vez que se negou a fazê-lo, seu caso foi levado ao Ministério Fiscal, perante o Juzgado Decano de Ávila, em 15 de janeiro de 1990, culminando por ser decidido pelo magistrado Jose Luis Calvo Cabello, na cidade de Madri, Espanha, em 03 de fevereiro de 1992.

Por guardar esse tema relação com a teoria do direito, pretende-se neste artigo analisar o caso de Añaki Arredondo Garcia, com vistas a distinguir desobediência civil, de objeção da consciência, sendo esses temas muito ricos na teoria jurídica atual, vez que tange à validade das normas, sua eficácia, abrangência, bem como o acatamento das mesmas por parte da população.

\section{A DESOBEDIÊNCIA CIVIL PARA HENRY DAVID THOREAU}

Antes de Henry David Thoreau, já o Código de Hamurabi vislumbrava a rebelião como uma punição ao mau governante e segundo Mariana Santiago de Sá ${ }^{5}$, Platão:

[...] afirmou com sabedoria: 'Obedecerei às leis e obedecerei a elas de bom grado quando digam respeito a qualquer interesse natural; por não fazê-lo, sereis filhos rebeldes e membros sem lealdade. Mas desobedecerei a elas até o desespero quando haja por motivo qualquer necessidade suprema do espírito.

${ }^{4}$ RIVAS, Nicolas Garcia. Los delitos de insumisión en la legislación española. Disponível em: <https://www.boe.es/publicaciones/anuarios_derecho/abrir _pdf.php?id=ANU-P-1992-

30088100932_ANUARIO_DE_DERECHO_PENAL_Y_ CIENCIAS_PENALES_Los_delitos_de_insumisi\%F3n_e n_la_legislaci\%F3n_espa\%F1ola>. Acesso em 06 jun. 2016.

${ }^{5}$ SANTIAGO DE SÁ, Mariana. Desobediência civil: um meio de se exercer a cidadania. Disponível em: < http://www.direitonet.com.br/artigos/exibir/2465/Desobedi encia-civil-um-meio-de-se-exercer-a-cidadania>. Acesso em 06 jun. 2016. 
Mas, quando se aborda a temática desobediência civil, é imperioso citar Thoreau ${ }^{6}$, uma vez que além de ter escrito pela primeira vez um texto situando o tema desobediência civil, foi ele mesmo preso por se negar ao pagamento de impostos ao seu País (EUA), pois entendia que esse dinheiro seria usado em uma guerra injusta que pelos anos de 1846 a 1848, os norteamericanos travavam com o México, quando as tropas dos Estados Unidos invadiram o país vizinho, sendo que a guerra só teve fim quando foi assinado um tratado em que o governo do México reconhecia como pertencente aos Estados Unidos o território que hoje compõe grande parte dos estados do Novo México, do Texas e da Califórnia.

Do cárcere, Thoreau escreve contra aquilo que acredita ser um crime praticado por seu país, concitando seus concidadãos a simplesmente não pagar a taxa de impostos, pois inclusive a guerra entre os dois países destinava-se à manutenção do sistema de escravidão então vigente, do qual era contra Thoreau, que assim disserta logo no começo de sua obra ${ }^{7}$ :

Será que o cidadão deve desistir de sua consciência, mesmo por um único instante ou em última instância, e se dobrar ao legislador? Por que então estará cada pessoa dotada de uma consciência? Em minha opinião devemos ser primeiramente homens, e só posteriormente súditos. Cultivar o respeito às leis não é desejável no mesmo plano do respeito aos direitos. A única obrigação que tenho direito de assumir é fazer a qualquer momento aquilo que julgo certo. Com toda razão, costuma-se dizer que uma corporação não tem consciência. Uma corporação de homens conscienciosos, todavia, é uma corporação consciente. O respeito reverente pela lei tem levado até mesmo os bem intencionados a agir quotidianamente como mensageiros da injustiça.

$\mathrm{O}$ que se nota é que Thoreau confunde desobediência civil com objeção da consciência, pois admitindo-se a primeira como um ato

\footnotetext{
${ }^{6}$ THOREAU, Henry David. A desobediência civil e outros escritos. $1^{\text {a }}$. ed. São Paulo-SP: Martin Claret, 2002.

${ }^{7}$ THOREAU, Henry David. A desobediência civil e outros escritos. 1a . ed. São Paulo-SP: Martin Claret, 2002, p. 15.
}

político, tendente a arregimentar pessoas para uma causa e a segunda, como um ato de foro íntimo, que não se pretende sequer seja noticiado, Thoreau em seu texto acaba por confundir ambos os institutos, sendo que já disseram que aquilo que para Gandhi era objeção de consciência, na verdade era desobediência civil, e o inverso para Thoreau.

Há trechos da obra Desobediência Civil, de Henry Thoreau, nos quais seu autor parece estimular inclusive a revolução, como quando alude ao aumento da ineficiência e da tiraria governamental ${ }^{8}$ : "O direito à revolução é reconhecido por todos, isto é, o direito de negar lealdade e de oferecer resistência ao governo sempre que se tornem grandes e insuportáveis sua tirania e ineficiência".

Ou seja, se Thoreau alertou a todos para a necessidade de se discutirem esses institutos, não se pode usar seu livro como parâmetro seguro para diferenciar o que seja desobediência civil, objeção de consciência, revolução ou um simples ato de descumprimento da lei.

\section{A DESOBEDIÊNCIA CIVIL PARA RONALD DWORKIN}

Ronald Dworkin, o segundo autor a se analisar, contempla uma visão interessante da desobediência civil, na medida em que parece querer coaduná-la com o sistema judicial norteamericano, de maneira que conviva sem causar danos ao governo como um todo. De início, Dworkin ${ }^{9}$ reprova que se interpretem os desobedientes, para ele dissidentes, como anarquistas, começando por lembrar de um argumento forte, no sentido de que a lei seja aplicada a todos, independentemente do que leva as pessoas a descumprirem-na:

\footnotetext{
${ }^{8}$ Op. cit., p. 17 .

${ }^{9}$ DWORKIN, Ronald. Levando os direitos a sério. 1. Ed.: São Paulo: Martins Fontes, 2002, p. 315.
} 
Pensam que os dissidentes são anarquistas que devem ser punidos antes que a corrupção se dissemine. Entretanto, muitos juristas e intelectuais chegam à mesma conclusão, baseados no que parece ser um argumento mais sofisticado. Eles reconhecem que a desobediência à lei pode ser moralmente justificada, mas insistem em que ela não pode ser legalmente justificada e pensam que desse truísmo se deduz que a lei deve ser aplicada.

Contudo, Dworkin ${ }^{10}$ lembra que a sociedade também não vai acabar se tolerar alguma desobediência civil: "A sociedade 'não pode manter-se' se tolerar toda e qualquer desobediência; daí não se segue, contudo, que ela irá desmoronar se tolerar alguma desobediência [...].".

Dworkin trabalha com uma situação mais extrema que a do jovem Añaki Arredondo Garcia, na medida em que analisa uma situação de guerra, como a dos EUA contra o Vietnã, e de dissidentes que se negaram a ir para o campo de batalha. Ao passo que a situação do jovem Añaki é diferente, porque se negou apenas ao cumprimento de medida alternativa ao serviço militar, em um período no qual seu país não estava em guerra.

Inobstante isso, Dworkin ${ }^{11}$ tenta dar diretrizes aos dissidentes, justificativas, contemplando três possibilidades em que o descumprimento da lei, deveria ser visto pelas autoridades, com um olhar mais ameno: a - se a lei for duvidosa, obscura, mas alertando o autor de que nesse caso, melhor seria que se cumprisse a lei, devendo o dissidente "imaginar o pior"; $b$ - se a lei for duvidosa, situação na qual o dissidente deveria seguir seu próprio discernimento, fazendo o que desejasse e c- sendo a lei duvidosa, e já houvesse uma decisão judicial contrária à dissidência, nos moldes em que o dissidente pretendia cometê-la, proibindo a dissidência, deveria cumprir a lei.

O que se percebe é que Dworkin não define os institutos da desobediência civil e da objeção de consciência, encarecendo a necessidade de haver dubiedade na lei, para que justifique qualquer dissidência, disciplinando com esse nome todas as formas de descumprimento da lei reconhecendo que, em virtude de algumas leis serem dúbias, e que o governo teria responsabilidade especial em proteger os dissidentes, não há garantias de que possa assegura-lhe imunidade.

Também não ajuda a análise de Dworkin ${ }^{12}$ sobre o caso da negativa de alistamento militar dos jovens, sendo que o autor mais pontua controvérsias, do que propriamente arremata soluções, parecendo contemporizar os interesses dos insubmissos com os interesses estatais, em uma relação difícil de conceber, sobretudo durante uma conflagração:

\begin{abstract}
Os casos de homens que se recusaram a aceitar o alistamento são mais complicados. A questão central é se a decisão de não processá-los induziria a recusas em massa de prestar serviço militar. Pode ser que não - havia pressões sociais, inclusive a ameaça de prejuízos para suas carreiras, que teriam forçado muitos jovens americanos a servir enquanto recrutados, mesmo que soubessem que não iriam para a cadeia caso se recusassem a fazê-lo. Se o número não tivesse aumentado muito, o Estado deveria ter deixado os dissidentes em paz - e não vejo que grande dano poderia ter ocorrido caso os processos tivessem sido adiados até que o efeito dessa política tivesse se tornado mais claro. Se o número daqueles que se recusavam ao alistamento se revelasse grande, isso contaria a favor da instauração de processos. Mas também tornaria o problema acadêmico, porque se as dissidências tivessem sido suficiente para conduzir a uma tal situação, de qualquer modo teria sido muito mais difícil de levar adiante a guerra, a não ser sob um regime quase totalitário.
\end{abstract}

Percebe-se a dubiedade nesse trecho da doutrina de Dworkin, que não ratifica como justo o ato de desobediência, nem contempla a objeção íntima, tentando contemporizar os interesses do governo com os interesses dos dissidentes, o que

\footnotetext{
${ }^{10}$ Op. cit., p. 316.

${ }^{11}$ Op. cit., p. 322.
}

${ }^{12}$ Op. cit., p. 336. 
parece incompossível de se coadunar em uma situação extrema de guerra.

Contudo, como bem esclarece Thamy Pogrebinschi ${ }^{13}$, Dworkin, ao contrário dos demais autores, não parte de uma análise moral que busque justificar os atos dos desobedientes civis e dos objetores de consciência, mas busca sua justificação jurídica. Ou seja, Dworkin não se preocupa em conceituar o que sejam esses institutos, mas busca analisar se atos de insurgência às leis devem ou não levar ao processamento dos dissidentes, por parte do Estado.

Dworkin chega a defender que os insurgentes não sejam punidos, não sejam criminalizados pelo Estado, mas tenta arrimar sua tese na incerteza das leis, na dúvida que as mesmas possam suscitar nos cidadãos. Usando a situação da Guerra do Vietnã e dos desertores do seu país, os EUA, esse jurista entende que os cidadãos podem descumprir leis que consideram inconstitucionais e mais ainda, podem descumprir decisões da Suprema Corte que violem as suas consciências, pois cumprir essas decisões significaria abdicar da única possibilidade de manifestar sua crença na inconstitucionalidade das leis.

Segundo Thamy Pogrebinschi ${ }^{14}$ essa forma de interpretar a lei, a jurisprudência e se voltar contra as mesmas é um direito social dos indivíduos, mas aqui é importante que se pontue que é comum a Suprema Corte dos EUA rever suas decisões, possuindo mais força neste país o chamado Direito Jurisprudencial:

Esta recusa em aceitar determinadas decisões da Suprema Corte como conclusivas é, segundo

\footnotetext{
${ }^{13}$ POGREBINSCHI, Thamy. O direito de resistência na teoria política contemporânea. Revista Lugar Comum Estudos de Mídia, Cultura e Democracia, n. 19-20, LATeC - Laboratório Território e Comunicação, UFRJ e Rede Universidade Nômade, junho 2004.

${ }^{14}$ Op. cit., p. 71.

${ }^{15}$ ZAMORA, Paula López. Análisis comparativo entre la desobediência civil y la objeción de consciência. Disponível
}

Dworkin, um direito social dos indivíduos. É preciso que se separe o caso do cidadão que viola a sua própria consciência quando ele sabe que a lei requer que ele faça isso, do caso do cidadão que é obrigado a desrespeitar a sua consciência mesmo acreditando que a lei não lhe exige isso. Esta última hipótese implicaria em retirar dos cidadãos uma das únicas chances que eles têm de mostrar para a sociedade que determinada lei é, para eles, inconstitucional.

Ou seja, a teoria de Dworkin, para justificar a desobediência civil, parece se amoldar ao sistema jurídico de seu país, quando o que se busca são conceitos que universalizem as interpretações a respeito de ambos os institutos, a desobediência civil e a objeção de consciência.

\section{DESOBEDIÊNCIA CIVIL E OBJEÇÃO DE CONSCIÊNCIA PARA PAULA L. ZAMORA}

Professora Associada de Filosofia do Direito da Universidade Complutense de Madri, Paula López Zamora escreveu importante artigo sobre a distinção entre desobediência civil e objeção da consciência ${ }^{15}$ e, após acentuar que ambos os institutos possuem pontos de encontro, destacando-se na verdade por suas diferenças, que lhes dão existência própria.

A princípio, a desobediência civil e a objeção de consciência seriam formas de desobedecer ao direito, sendo que alguns teóricos, como R. Soriano ${ }^{16}$ entendem que há uma relação de gênero e espécie, entre ambos os institutos, sendo a objeção de consciência uma classe da desobediência civil, ou uma das manifestações da desobediência civil, o mais certo é que há distinções importantes, não podendo se confundir desobediência civil com outras formas de dissidência.

em:

<https://revistas.ucm.es/index.php/ANDH/article/viewFile/ ANDH0202110317A/20968>. Acesso em 20 mai. 2016.

${ }^{16}$ SORIANO, R. La objeción de consciência: significado, fundamentos jurídicos y postivación en el ordenamento jurídico español. Revista de Estudios Políticos n. 58, Nov/Dec 1987, p. 64. 
A primeira grande diferença apontada por Paula López Zamora ${ }^{17}$ é que enquanto a objeção de consciência tem um fundamento moral, a desobediência civil teria um fundamento político, mas não ficaria apenas nisso a distinção, pois segundo a autora ${ }^{18}$ :

La grave dificultad para encontrar en los sucesos facticos una línea claramente diferenciadora entre desobediência civil y objeción de consciência es reconocida por la mayoría de los autores, no obstante, esto no há sido impedimento para que la doctrina examine exhaustivamente cuales son los puntos que, en la teoria más que en la práctica, enfrentan a ambas figuras.

Mas, segundo a autora, além da diferença citada anteriormente, de que a desobediência civil teria um fundamento político, ao passo que a objeção de consciência, um fundamento moral, outros pontos servem para divisar ambos os institutos, como por exemplo:

A - Os sujeitos: a desobediência civil é um ato de desobediência ao direito que requer uma realização coletiva, ao passo que a objeção de consciência quase sempre é individual. Mesmo que haja mais de um objetor de consciência, sendo que ambos ou todos tenham a mesma razão comum a objetar, o fato é que cada um deles:

[...] lucha por su própria consciência e no se produce una identificación en la reivindicacion con el resto, aunque puede ocurrir que se logre una organización y poco a poco lo que nació como objeción de consciência se transforme en desobediência civil ${ }^{19}$;

B - A desobediência civil encontra seu fundamento em aspectos políticos, já a objeção de consciência, em motivos éticos. Contudo, tal critério acaba por se tornar falho, na medida em

\footnotetext{
${ }^{17}$ Op. cit., p. 321.

${ }^{18}$ Op. cit. p. 323.

${ }^{19}$ ZAMORA, Paula López. Análisis comparativo entre la desobediência civil y la objeción de consciência. <https://revistas.ucm.es/index.php/ANDH/article/viewFile/
}

que, como alerta Zamora ${ }^{20}$, tanto em um, quanto em outro instituto, os motivos podem se confundir. Mas pode-se asseverar, como mais um possível elemento diferenciador, que a objeção de consciência nasce de motivações morais e éticas, ao passo que a desobediência civil se origina de causas políticas;

C - Destino de ambos os institutos, após materializarem-se na prática: os atos de objeção de consciência têm uma tendência a serem acoimados pelo direito, originando leis que contemplem essa situação como exceções em que se pode descumprir a lei. Já a desobediência civil possui uma tendência a nunca se institucionalizar juridicamente, fadada a ser sempre um ato de desobediência ao direito;

D - Manifestação: a desobediência civil anseia por se tornar pública. Em outras palavras, o desobediente espera, com seu ato, a publicidade, com a qual imagina angariar apoio e produzir novos atos de desobediência. Já na objeção de consciência, o objetor quase sempre adota uma reação privada, discreta, de descumprimento da norma, sendo que apenas acidentalmente tal situação se torna do conhecimento público, alertando Paula L. Zamora ${ }^{21}$, que já houve autores que destacaram como elemento diferenciador entre os dois institutos, a possibilidade de a desobediência civil desembocar em atos de danos a terceiros, ao passo que isso seria inadmissível no caso da objeção de consciência;

E - A heterogeneidade face ao objeto da desobediência: aqui trata-se de analisar o dever jurídico descumprido, por exemplo os constantes casos de invasão de terra, que são praticados pelo Movimento dos Sem Terra, no Brasil. Seria

ANDH0202110317A/20968>. Acesso em 20 mai. 2016, p. 324.

${ }^{20}$ Op. cit. p. 325 .

${ }^{21}$ Op. cit., p. 328. 
indubitavelmente caso de desobediência civil, pois segundo Zamora ${ }^{22}$ :

La objeción de consciencia siempre viola un deber de tipo positivo, un deber consiste en un hacer o dar algo, por lo que los actos del objetor siempre serán omisivos. Por el contrario, los actos del desobediente civil podrán ser tanto omisivos como comisivos, ya que el deber que incumplen puede ser tanto de tipo positivo como de tipo negativo, si bien es cierto que para determinados autores la desobediência civil constituye siempre un comportamento comisivo, es decir, el incumplimiento de prohibiciones.

Também é comum usar como diferenciação entre desobediência civil e objeção de consciência o fato de que o primeiro instituto violaria deveres, obrigações de caráter real, ao passo que o segundo, atingiria deveres pessoais;

F - Finalidade: trata-se, ainda segundo Zamora $^{23}$, do critério mais exaustivamente utilizado para fazer uma diferenciação entre desobediência civil e objeção de consciência. Os desobedientes civis possuem a intenção de mudar as instituições políticas ou jurídicas, esperando que uma norma injusta seja modificada, ao passo que os objetores de consciência perseguiriam uma finalidade privada, não desejando, a princípio, que haja mudança na lei ou na ordem jurídica, pretendendo apenas que para o seu caso, a aplicação da norma seja afastada, pois segundo a autora 24 "Parafraseando a L. Prieto Sanchís entendemos que el objetor rehúsa el cumplimiento de una norma porque es injusta, no para que deje de serlo";

\footnotetext{
${ }^{22}$ Op. cit. p. 330-331.

${ }^{23}$ Op. cit., p. 332.

${ }^{24}$ ZAMORA, Paula López. Análisis comparativo entre la desobediência civil y la objeción de consciência. Disponível em:

<https://revistas.ucm.es/index.php/ANDH/article/viewFile/ ANDH0202110317A/20968>. Acesso em 20 mai. 2016, p. 333.
}

$\mathrm{G}$ - Por fim, a atitude diante do castigo pelo descumprimento legal: o desobediente civil normalmente aceita as penas impostas pelo Estado, em virtude de sua desobediência, ao passo que o objetor de consciência não raro tenta fugir da reprimenda, se escondendo ou imigrando. Aqui, em verdade não é um critério tão sólido para que se diferencie ambos os institutos, pois lembrase, a respeito do caso de Añaki Arredondo Garcia, que manifestou desejo de não recorrer da sentença criminal, caso fosse condenado por descumprimento do serviço substitutivo à dispensa do serviço militar obrigatório, na Espanha.

Tem-se, assim, os primeiros critérios para se distinguir desobediência civil, de objeção de consciência, que serão enriquecidos pelas opiniões dos próximos juristas.

\section{A DESOBEDIÊNCIA CIVIL PARA MARTHA E. S. OBRÉGON E RAÚL RUIZ CANIZALES, COMPARADOS COM A OPINIÃO DE JESUS LIMA TORRADO}

\section{Martha Elena Soto Obregón e Raúl Ruiz} Canizales ${ }^{25}$ também empreenderam valioso esforço na tentativa de diferenciar os institutos estudados, citando inclusive doutrina do Professor Jesus Lima Torrado. Após pontuar que tanto a desobediência civil, quanto a objeção de consciência representam figuras à margem da lei, da mesma forma como o são a dissidência simples, a resistência constitucional, a resistência revolucionária, a rebelião, a sabotagem, a desobediência criminal e a revolução.

\footnotetext{
${ }^{25}$ CANIZALES, Raúl Ruiz; OBRÉGON, Martha Elena Soto. Tratamiento "habitual" de lá objeción de conciência (oc) y la desobediência civil (dc) en la teoria del derecho. Disponível em $<$ http://www.corteidh.or.cr/tablas/r30815.pdf $>$ Acesso em 25 abr. 2016.
} 
Citando Marina Gascón Abellan e o pensamento rawlsiano, lembram que a desobediência civil não pretende acabar com o sistema constituído, mas antes de tudo, melhorálo e que nas opiniões de Mario Alvarez e Jesus Lima Torrado ${ }^{26}$, na objeção de consciência o objetor descumpre lei que contraria suas convicções íntimas, ao passo que na desobediência civil os dissidentes descumprem disposição que causa maior impacto social, como aqueles grupos que se negam a pagar impostos, comunicando sua decisão às autoridades competentes, aumentando a possibilidade de serem atendidos em seu pleito.

$\mathrm{E}$ aqui torna-se importante, finalmente, distinguir desobediência civil direta, de desobediência civil indireta, pois como pontuam Canizales e Obrégon ${ }^{27}$, citando doutrina de José Antonio Esteves Araújo:

LIMA TORRADO acude a ESTÉVEZ ARAUJO para fortalecer su distinción entre desobediência civil directa e indirecta:

'La distinción entre desobediência civil indirecta y directa es habitualmente manejada por la doctrina académica. La desobediência civil directa es aquélla que consiste en la violación de las normas que contribuyen el objeto de la protesta; por ejemplo la negativa de la señora Parks a ceder su asiento a un pasajero blanco, contraviniendo así la normativa discriminatória de los autobuses de Montgomery. La desobediência civil indirecta se daría cuando las normas violadas fuesen diferentes de las que contribuyen el objeto de la protesta. Suele añadirse, además, que las normas efetivamente desobedecidas no tienen nada recriminable desde el punto de vista de los desobedientes.

Norberto Bobbio ${ }^{28}$ usa a expressão contestação e resistência, sendo que se esta levaria a um ato prático, em uma ação que mostrasse a não aceitação de uma determinada situação, aquela seria à manifestação verbal, buscando arregimentar apoio:

\footnotetext{
${ }^{26}$ Op. cit., p. 24.

${ }^{27}$ Op. cit., p. 25.

${ }^{28}$ BOBBIO, Norberto. A era dos direitos. 9a. Ed. Rio de

Janeiro: Campus/Elsevier, 2004, p. 152-153.
}

\begin{abstract}
Enquanto contrária à aceitação, a contestação se refere, mais do que a um comportamento de ruptura, a uma atitude de crítica, que põe em questão a ordem constituída sem necessariamente pô-la em crise. Lavau observa, corretamente, que a contestação 'supera o âmbito do subsistema político para atingir não só sua ordem normativa, mas também os modelos culturais gerais (o sistema cultural) que asseguram a legitimidade profunda do subsistema político'. E, com efeito, se a resistência culmina essencialmente num ato prático, numa ação ainda que apenas demonstrativa (como a do negro que se senta à mesa de um restaurante reservado a brancos), a contestação, por seu turno, expressa-se através de um discurso acrítico, num processo verbal, na enunciação de um slogan.
\end{abstract}

Segundo Bobbio, a violência do contestador (se é certo chamar a isso de violência) é sempre apenas ideológica. Mais correto, então, voltando ao caso sob análise, seria afirmar que Añaki Arredondo adotou uma postura de não-violêncianegativa, que segundo Norberto Bobbio trata-se de uma resistência passiva, não violenta, às leis injustas ou às leis que se chocam com a dignidade humana, sua forma de ver o mundo e de interagir com o mesmo. Sendo que atualmente, preferemse os atos de resistência ativa, ou seja, de nãoviolência-positiva, que vem a ser a resistência, acompanhada de ações afirmativas, aptas a mostrar ao opressor, chamado por Bobbio de adversário, que a intenção não é apenas confrontálo ou descumprir ordem estatal, mas que é possível, parafraseando Bobbio ${ }^{29}$ : “... construir um modo melhor de convivência com o qual o próprio adversário deverá se beneficiar.”.

\section{CONCLUSÃO}

É inequívoco haver clara distinção entre desobediência civil e objeção de consciência. Por mais que ambos os institutos uma vez ou outra se confundam, os autores citados apontam na

${ }^{29}$ Op. cit., p. 163. 
direção de que é possível estabelecer critérios de distinção. Pode-se apontar um gênero que contemple ambos os institutos, contudo esse deve ser denominado simplesmente de descumprimento ao direito, o qual admite várias formas e sub-formas.

Ficou bastante evidente nesta exposição, que a espécie de descumprimento ao direito, denominada desobediência civil é: a - um ato público, incompatível com o motim e com as conspirações, que não pode encampar a violência, exceto contra a propriedade, naqueles casos de invasão, por parte de quem luta para que se cumpram os anseios constitucionais, no que pertine às políticas públicas e acesso aos bens, às classes menos favorecidas; $b$ - um ato político, de quem pretende torná-lo conhecido, arregimentando defensores e outros desobedientes, tendentes à mudança da lei que se considera injusta; $\mathrm{c}$ - o último recurso, uma vez transpostos todos os caminhos legais e judiciais para se modificar a lei, ou para se evitar ser atingido por seus efeitos danosos.

Já a objeção de consciência é um ato no qual: a - se invocam razões de consciência, para o descumprimento da lei; $\mathrm{b}$ - $\mathrm{a}$ vontade do objetor não entra em conflito com a vontade da maioria $\mathrm{e}$ tampouco se deseja que aquela norma descumprida seja revogada, mas apenas e tãosomente que deixe de ser aplicada ao objetor; c não se busca, com sua prática, os holofotes, a atenção da mídia, pois o objetor pretende apenas ficar livre, ser eximido do cumprimento de uma determinada obrigação legal, pouco lhe importando que a sociedade tome conhecimento disso, mesmo que isso acabe acontecendo, talvez acidentalmente; $\mathrm{d}$ - pretende-se demonstrar ao Estado que uma determinada norma é injusta, no tocante as convicções íntimas do objetor, sendo que no cerne dessa imposição por parte do Estado, há uma ofensa à dignidade da pessoa humana e à individualidade, enquanto direito de cada ser humano agir como determina a sua consciência e viver em coletividade, se assim o desejar, mas mantendo intocados os seus valores, a sua visão de mundo, da vida e da morte, bem como de sua posição e condição no mundo.

No caso do jovem Añaki Arredondo Garcia notam-se todas as características da objeção de consciência, pontuando o magistrado que o absolveu, que o acusado se negou à prestação do serviço substitutivo motivado por suas convicções íntimas, de cunho religioso. O mesmo não apresentou objeção contra o cumprimento do serviço militar, mas questionou a própria necessidade de sua existência.

Mesmo que o magistrado prolator da sentença, Jose Luis Calvo Cabello, em determinado ponto da sua decisão, enxergue na insubmissão de Añaki, um ato de desobediência civil, forçoso reconhecer ante à distinção feita anteriormente, que de desobediência civil não se tratou, valendo transcrever parte fundamental da decisão, que por seus próprios argumentos, representa verdadeiro libelo à liberdade e à dignidade da pessoa humana ${ }^{30}$ :

a) La consciencia, fuero intimo de la persona, no solo dice lo que está bien o lo que está mal, sino que puede imponer al hombre el compromiso de actuar conforme a si mismo, de desarrollarse de acuerdo con su convicciones, de ser lo que es;

b) La libertad de consciência es un derecho fundamental reconocido como libertad ideológica en el art. 16 de la Constituición - la libertad ideológica comporta esta dimensión basicamente ética - y, expressamente, como tal libertad de consciencia, en el art. 18 del Pacto Internacional de Derechos Civiles y Políticos;

c) La persona no es en la Constituición un resultado jurídico, sino presupuesto y fundamento del orden político y jurídico; la persona no es con el Derecho,

\footnotetext{
${ }^{30}$ ESPANHA. Administración de Justicia. Juzgado de lo Penal Madrid - n. 4. Sentencia num. 75/92 - 2I6190129. Juez Jose Luis Calvo Cabello. 03. Fev. 1992.
} 
sino que este dota de significación jurídica al ser humano existente;

d) La dignidade de la persona es, por expressa declaración constitucional, fundamento del orden político y de la paz social.

Não se imagine, contudo, que a sentença exarada pelo Magistrado espanhol tenha sido acolhida sem críticas. Como acentua Sonia Esperanza Rodrígues Boente ${ }^{31}$, situando esta decisão entre os casos ditos complicados, alerta que se tratou de "Un claro ejemplo de decisión contra legem [...]", sendo que o juiz se fundamentou inclusive na eximente do estado de necessidade, regulada no artigo $8^{\circ}$., número 7 , do Código Penal Espanhol, por considerar que houve um conflito entre dois bens de igual peso: a consciência individual de Añaki Arredondo Garcia e a Lei da Espanha, decidindo-se por amparar o primeiro.

Essa sempre será uma das grandes dificuldades dos magistrados que tiverem de sentenciar casos de desobediência civil e objeção de consciência, ou seja, de sentenciar contra leis, dificuldade que poderá ser transposta se valorarem a dignidade da pessoa humana acima de qualquer lei do seu país e se vislumbrarem que o descumprimento de uma norma é um mal menor ante o vilipêndio, ante à afronta da consciência humana, que conforme Henry David Thoreau é e sempre será irrenunciável.

\section{REFERÊNCIAS}

BOBBIO, Norberto. A era dos direitos. 9a. Ed. Rio de Janeiro: Campus/Elsevier, 2004.

\section{A era dos direitos. 1 ${ }^{\text {a }}$. Ed. Rio de Janeiro: Campus/Elsevier, 2004.}

BOENTE, Sonia Esperanza Rodrígues. La justificación de las decisiones jurídicas el artículo 120.3 de la Constituición Española. Universidade de Santiago de Compostella, 2003.

BUZANELLO, José Carlos. Objeção de consciência: uma questão constitucional. Revista de Informação Legislativa. Brasília a. 38 n. 152 out/dez 2001 (pág. 173/182) Disponível em : https://www2.senado.leg.br/bdsf/bitstream/handle/id/730/r152-13.pdf?sequence=4, Acesso em: 01 Dez. 2016.

CANIZALES, Raúl Ruiz; OBRÉGON, Martha Elena Soto. Tratamiento "habitual" de lá objeción de conciência (oc) y la desobediência civil (dc) en la teoria del derecho. Disponível em $<$ http://www.corteidh.or.cr/tablas/r30815.pdf> Acesso em: 25 abr. 2016.

DWORKIN, Ronald. Levando os direitos a sério. 1. Ed.: São Paulo: Martins Fontes, 2002.

ESPANHA. Administración de Justicia. Juzgado de lo Penal Madrid - n. 4. Sentencia num. 75/92 2I6190129. Juez Jose Luis Calvo Cabello. Publicada em 03. Fev. 1992.

HERNANDÉZ, António José. Un juez absuelve a un insumiso al entender que la libertad de consciência está por encima del Estado. Madri. Publicado em 7 mar. 1992. El País. Disponível em < http://elpais.com/diario/1992/03/07/espana/699922819_850215.html>. Acesso em: 20 mai.2016.

LIMA TORRADO, Jesus. Desobediencia civil y objecion de conciencia. Mexico, CNDH, série

${ }^{31}$ BOENTE, Sonia Esperanza Rodrígues. La justificación

Constituición Española. Universidade de Santiago de de las decisiones jurídicas el artículo 120.3 de la Compostella, 2003, p. 554-555. 
Cuaderno del Centro Nacional de Derechos Humanos, n. 4, 2000.

POGREBINSCHI, Thamy. $O$ direito de resistência na teoria política contemporânea. Revista Lugar Comum Estudos de Mídia, Cultura e Democracia, n. 19-20, LATeC - Laboratório Território e Comunicação, UFRJ e Rede Universidade Nômade, junho 2004.

RIVAS, Nicolas Garcia. Los delitos de insumisión en la legislación española. <https://www.boe.es/publicaciones/anuarios_derecho/abrir_pdf.php?id=ANU-P-1992-

30088100932_ANUARIO_DE_DERECHO_PENAL_Y_CIENCIAS_PENALES_Los_delitos_de_in sumisi\%F3n_en_la_legislaci\%F3n_espa\%F1ola>. Acesso em: 06 jun. 2016.

SANTIAGO DE SÁ, Mariana. Desobediência civil: um meio de se exercer a cidadania. < http://www.direitonet.com.br/artigos/exibir/2465/Desobediencia-civil-um-meio-de-se-exercer-acidadania>. Acesso em: 06 jun. 2016.

SORIANO, R. La objeción de consciência: significado, fundamentos jurídicos y postivación en el ordenamento jurídico español. Revista de Estudios Políticos n. 58, Nov/Dec 1987, p. 64

THOREAU, Henry David. A desobediência civil e outros escritos. $1^{\text {a }}$. ed. São Paulo-SP: Martin Claret, 2002.

TURRÓN, Pablo Iglesias. Desobediencia civil y movimiento anti-globalización, uma herramienta de intervencion politica. <https://www.academia.edu/4024498/Desobediencia_civil_y_movimiento_antiglobalizacion_Una_h erramienta_de_intervencion_politica>. Acesso em: 20 mai. 2016.

ZAMORA, Paula López. Análisis comparativo entre la desobediência civil y la objeción de consciência. Disponível em: <https://revistas.ucm.es/index.php/ANDH/article/viewFile/ANDH0202110317A/20968>. Acesso em: 20 mai. 2016. 
